\title{
PENINGKATAN MINAT DAN HASIL BELAJAR KONSEP SISTEM GERAK PADA MANUSIA MELALUI PEMBELAJARAN KOOPERATIF TGT PADA SISWA KELAS VIIID SMP NEGERI 1 BANDUNGAN
}

\author{
Eko Purwanti
}

\begin{abstract}
ABSTRAK
Pembelajaran secara konvensional membuat siswa cepat bosan dan tidak berminat untuk mengikuti pembelajaran dengan maksimal. Permasalahan yang timbul adalah bagaimana jika menggunakan model pembelajaran yang dapat mengaktifkan siswa. Rumusan masalah dalam penelitian ini adalah: (1) Bagaimana pembelajaran kooperatif TGT (Team Game Tournament) dapat meningkatkan minat belajar konsep sistem gerak pada manusia pada siswa kelas VIIID SMP Negeri 1 Bandungan tahun pelajaran 2013/2014. (2) Bagaimana pembelajaran kooperatif TGT dapat meningkatkan hasil belajar konsep sistem gerak pada manusia pada siswa kelas VIIID SMP Negeri 1 Bandungan tahun pelajaran 2013/2014. Tujuan penelitian ini untuk (1) Mendeskripsikan peningkatan minat belajar konsep sistem gerak pada manusia melalui pembelajaran kooperatif TGT pada siswa kelas VIIID SMP Negeri 1 Bandungan tahun pelajaran 2013/2014. (2) Mendeskripsikan peningkatan hasil belajar konsep sistem gerak pada manusia melalui pembelajaran kooperatif TGT pada siswa kelas VIIID SMP Negeri 1 Bandungan tahun pelajaran 2013/2014. Penelitian ini merupakan Penelitian Tindakan Kelas (Action Research) yang dirancang melalui dua siklus yaitu dengan prosedur: (1) Perencanaan (Planning), (2) Pelaksanaan tindakan (Acting), (3) pengamatan (Observing), (4) refleksi dalam tiap-tiap siklus (reflecting). Hasil penelitian ini adalah pembelajaran dengan kooperatif TGT dapat meningkatkan minat belajar siswa yang ditunjukkan dengan parttisipasi dalam pembelajaran sebesar 81,76\%, dan dapat meningkatkan hasil belajar siswa kelas VIIID tahun pelajaran 2013/2014 sebesar 19,7\%. Berdasarkan hasil penelitian direkomendasikan untuk diadakan penelitian lanjutan mengenai pembelajaran dengan model kooperatif TGT yang dapat meningkatkan aktifitas belajar siswa.
\end{abstract}

Kata kunci: Pembelajaran kooperatif TGT, minat, hasil belajar.

\section{PENDAHULUAN}

Pelajaran IPA merupakan salah satu mata pelajaran yang diberikan pada tingkat pendidikan dasar, termasuk di SMP. Pelajaran IPA memberikan kemampuan berpikir rasional terhadap gejalagejala alam dan lingkungan. Dengan belajar IPA siswa akan lebih peka terhadap lingkungannya, lebih memahami dirinya sehingga dapat meningkatkan keimanan dan ketaqwaannya terhadap Tuhan Yang Maha Esa.

Materi berbagai sistem dalam tubuh manusia, salah satunya kompetensi dasar mendeskripsikan sistem gerak pada manusia dan hubungannya dengan kesehatan akan membuat siswa lebih mengenal dirinya, menghindari hal buruk yang mengganggu kesehatan tubuhnya dan lebih mensyukuri nikmat Illahi. Hasil pengamatan dan dokumentasi menunjukkan bahwa nilai ulangan harian pada KD 1.2 Mendeskripsikan tahapan perkembangan manusia pada siswa kelas VIIID masih rendah, yaitu rataratanya hanya 6,1. Dan ketuntasan klasikal yaitu 85\% siswa tuntas KKM belum tercapai. KKM yang sudah ditetapkan sebesar 70. Siswa yang telah tuntas KKM sebanyak $42 \%$. 
Pembelajaran dengan metode ceramah dan tekstual membuat perhatian dan konsentrasi siswa terhadap pembelajaran hanya berlangsung singkat. Hal ini ditandai dengan adanya siswa yang ijin keluar kelas dan kurang bergairah pada waktu pembelajaran. Kondisi seperti ini tentu saja menyebabkan transfer materi pembelajaran terhambat, sehingga pencapaian hasil belajar menjadi tidak maksimal.

Merupakan tantangan bagi guru untuk bisa menyajikan pembelajaran yang bersifat mengaktifkan dan menyenangkan siswa, sehingga mereka tidak bosan berada dalam kelas dan mau mengikuti pelajaran dengan antusias. Untuk itu guru harus menampilkan model pembelajaran yang bervariasi dan menarik, salah satunya belajar melalui permainan. Melalui bermain, banyak yang dipelajari siswa. Mulai dari belajar bersosialisasi, menahan emosi, atau belajar hal lain, yang kesemuanya diperoleh secara terintegrasi. Mengingat bahwa (1) Anak belajar melalui berbuat/learning by doing, (2) Anak belajar melalui panca indera, (3) Anak belajar melalui bahasa, (4)Anak belajar dengan bergerak.

Usia siswa merupakan usia yang memiliki keterbatasan dalam berkonsentrasi. Semakin lama anak duduk dan diam, semakin bosan dan tidak tertarik terhadap apa yang sedang dipelajari. Siswa perlu dimotivasi dengan menggerakkan seluruh bagian tubuh, seperti tangan, kaki, badan, dan kepala. Model pembelajaran kooperatif TGT merupakan salah satu solusi untuk dapat mengaktifkan siswa dalam belajar. Model pembelajaran ini dilakukan dengan permainan kartu soal yang dilaksanakan dalam kelompok-kelompok, sehingga dapat meningkatkan aktifitas siswa secara keseluruhan.

Melihat keunggulan model pembelajaran kooperatif TGT dalam meningkatkan aktifitas siswa dalam belajar dan rendahnya hasil belajar siwa VIIID SMPN 1 Bandungan pada konsep pertumbuhan dan perkembangan padahal materi tersebut merupakan materi esensi, maka peneliti tertarik untuk menggunakan pembelajaran kooperatif TGT pada pembelajaran konsep sistem gerak pada manusia pada kelas VIII.

Rumusan masalah pada penelitian ini adalah bagaimanakah model pembelajaran kooperatif TGT dapat meningkatkan minat dan hasil belajar konsep sistem gerak pada manusia pada siswa kelas VIIID SMP N tahun pelajaran 2013/2014?

Tujuan penelitian ini adalah untuk mengetahui bahwa dengan pembelajaran kooperatif TGT minat dan hasil belajar konsep sistem gerak pada manusia pada siswa kelas VIIID SMP N 1 Bandungan tahun pelajaran 2013/2014 akan meningkat. Mulai siklus pertama, pemahaman akan sistem gerak akan meningkat, sehingga pada akhir siklus kedua akan dapat mencapai ketuntasan KKM yaitu 70 minimal 85 persen. 
Manfaat penelitian ini diantaranya dapat meningkatkan aktifitas belajar siswa, sehingga hasil belajar khususnya konsep sistem gerak pada manusia dapat meningkat. Bagi guru dapat memberikan alternatif metode pembelajaran yang variatif dan mengatasi masalah pembelajaran terutama berkaitan dengan pembelajaran IPA.

\section{METODE PENELITIAN}

Penelitian ini merupakan penelitian tindakan kelas, yang dilakukan dalam dua siklus pada siswa kelas VIIID SMP N 1 Bandungan yang berjumlah 31 siswa. Masing-masing siklus terdiri dari kegiatan perencanaan, pelaksanaan tindakan, pengamatan atau observasi, dan refleksi.

Instrumen pengambilan data dalam penelitian ini berupa lembar observasi pembelajaran, pedoman wawancara, dan soal tes. Teknik pengambilan data dengan observasi, wawancara, dokumen, dan tes tertulis. Data-data yang terkumpul dianalisis dengan cara diskriptif, diklasifikasikan, diinterpretasikan, dan dideskripsikan ke dalam bahasa verbal untuk penarikan kesimpulan.

Indikator keberhasilan penelitian ini adalah adanya peningkatan minat belajar dan pemahaman konsep system gerak pada manusia dengan tolok ukur pada akhir siklus kedua nilai ulangan harian dapat mencapai KKM yaitu 70 dengan ketuntasan kelas mencapai 85 persen. Peningkatan minat belajar siswa ditunjukkan dengan respon siswa terhadap pembelajaran mencapai 80 persen.

\section{HASIL PENELITIAN DAN PEMBAHASAN}

Pada pertemuan awal, saat membahas materi pertumbuhan dan perkembangan makhluk hidup, peneliti menggunakan metode konvensional yaitu ceramah yang divariasi dengan tanya jawab. Dengan metode konvensional menunjukkan hasil yang belum memuaskan. Rata-rata nilai ulangan 60,97 dan prosentase ketuntasan klasikal baru mencapai 41,94 persen. Ketuntasan hasil belajar secara klasikal tersebut, masih sangat jauh dari semestinya yaitu $85 \%$.

Melihat kondisi hasil belajar yang rendah itulah maka penulis melakukan Penelitian Tindakan Kelas (PTK). Penelitian ini dilaksanakan dalam dua siklus. Tiap-tiap siklus terdiri dari perencanaan, tindakan, observasi dan refleksi.

\section{Siklus I}

Perencaan diawali dengan pembuatan perangkat pembelajaran yang terlebih dahulu divalidasi oleh observer sehingga didapatkan perangkat pembelajaran yang terbaik. Penilaian perangkat oleh observer termasuk kategori baik. 
Pelaksanaan penelitian di kelas VIIID, dimulai dengan membagi siswa menjadi 10 kelompok, masing-masing kelompok 3 siswa. observer Sugito, S.Pd., M.Pd. Materi yang diberikan mengenai fungsi rangka, jenis tulang, macam tulang dan persendian.

Pada siklus I, setelah menerima penjelasan materi secara garis besar, siswa berdiskusi mengerjakan LKS, dilanjutkan dengan tournament antar kelompok. Dalam kegiatan tournament dibuat dua meja tournament dan tiap kelompok mewakilkan satu anggota. Selesai permainan tiap-tiap kelompok menjumlah skor yang diperoleh pada masing-masing meja tournament dan merupakan nilai kelompok. Kelompok yang memperoleh skor tertinggi merupakan pemenang. Permainan pada siklus I dimenangkan oleh kelompok $\mathrm{H}$.

Setelah selesai pembelajaran siswa diberikan post tes oleh guru. Nilai post tes menunjukkan adanya peningkatan nilai rata-rata yaitu dari 60,97 menjadi 66,65 namun ketuntasan secara klasikal belum meningkat.

Dari pengamatan selama proses pembelajaran ada beberapa hal yang perlu diperhatikan, diantaranya (1) pada siklus yang pertama ini, karena belum pernah belajar dengan permainan maka pembimbingan terhadap siswa perlu ditingkatkan; (2) perlu diperhatikan untuk siswa yang kurang aktif dan kurang bisa bekerjasama dalam kelompoknya; (3) perlu perhatian lebih untuk anak yang lemah dan suka mengganggu temannya.

Hasil diskusi observer dengan peneliti, peneliti menganalisa, mempertimbangkan dan pada akhirnya menyepakati untuk membenahi kekurangan-kekurangan yang terjadi pada siklus I pada perencanaan pembelajaran di siklus II.

\section{Siklus II}

Pada siklus kedua perangkat pembelajaran mengalami sedikit perubahan yaitu pengurangan waktu untuk penjelasan guru dan waktu untuk bermainnya lebih lama. Hal ini bertujuan untuk meningkatkan aktifitas siswa dalam proses pembelajaran, sehingga siswa dapat lebih memahami untuk materi otot dan gangguan pada system gerak.

Pada saat proses pembelajaran berlangsung direncanakan peneliti akan (1) menekankan kembali tentang aturan dalam permainan TGT, sehingga waktu menjadi lebih efektif; (2) meningkatkan perhatian terhadap siswa yang kurang aktif dan kurang bisa bekerjasama dalam kelompoknya; (3) memberikan perhatian lebih untuk anak yang lemah dan suka mengganggu temannya.

Observer mencatat hal-hal yang kurang sesuai terhadap pelaksanaan pembelajaran, baik dari segi pengelolaan kelas, penguasaan materi, keaktifan siswa, perilaku peneliti serta kesesuaian antara perencanaan dan pelaksanaannya. 
Soal post tes untuk siklus kedua berbentuk soal uraian dan termasuk ranah ingatan dan pemahaman.

Pelaksanaan penelitian di kelas VIIID, materi pelajaran yang diberikan meliputi otot dan gangguan pada system gerak. Peneliti lebih menekankan pada proses permainan TGT nya. Permainan yang pada siklus I hanya dua putaran soal, pada siklus II ditambah menjadi minimal empat kali putaran soal. Dengan tujuan agar pemahaman siswa pada materi otot dan gangguan system gerak lebih meningkat. Tournamen pada siklus II dimenangkan oleh kelompok D. Setelah selesai permainan siswa diberikan post tes oleh guru. Hasil post tes siklus II menunjukkan peningkatan baik rata-rata nilai maupun ketuntasan secara klasikal.

Dari pengamatan selama proses pembelajaran siklus II hampir semuanya berjalan sesuai dengan rencana. Aktivitas siswa dalam pembelajaran cukup tinggi, dilihat dari antusiasme siswa dalam mengikuti pelajaran. Permainan tournament juga lancar dan berjalan sesuai rencana. Observer menyarankan untuk menggunakan model pembelajaran TGT pada materi pembelajaran yang lain, terutama materi pelajaran yang sifatnya banyak menghafal.

\section{Pembahasan}

Pada awal pembelajaran siklus I kondisi kelas berbeda dari sebelumnya. Suasana kelas nampak sunyi, bahkan kelihatan ada rasa takut. Hal ini terjadi karena ada dua orang guru yang masuk ke kelas, yaitu peneliti (guru pengajar) dan pengamat (observer). Ketika guru menyampaikan materi, tujuan pembelajaran dan KKM yang harus dicapai semua siswa diam dan kelihatan tegang. Suasana kelas kelihatan hidup setelah diberi kesempatan berdiskusi dalam kelompok sebelum tournament berlangsung.

Pada waktu diskusi kelompok maupun TGT berlangsung semua siswa kelihatan aktif dalam proses pembelajaran. Bahkan beberapa siswa menunjukkan ekspresi kegembiraan selama kegiatan permainan berlangsung. Hal ini tentunya akan membawa dampak positif terhadap hasil belajarnya. Ini sesuai dengan pendapatnya Slameto, bahwa dalam belajar setiap siswa harus diusahakan partisipasi aktif, meningkatkan minat dan membimbing untuk mencapai tujuan instruksional. Penerimaan pelajaran yang didapat dari aktivitas siswa sendiri, tidak akan hilang begitu saja kesannya, tetapi akan dipikirkan dan diolah sehingga siswa akan memiliki ilmu/pengetahuan itu dengan baik (Slameto,2010:36).

Dengan pembelajaran TGT aktivitas siswa berdasarkan pengamatan observer mencapai 81,76\%. Aktivitas belajar yang tinggi menunjukkan minat siswa terhadap proses pembelajaran yang sedang berlangsung. Tingginya minat belajar siswa juga dapat dilihat dari besarnya respon siswa terhadap 
pembelajaran TGT pada materi system gerak yang mencapai $85,5 \%$. Tingginya aktivitas dan minat siswa dalam pembelajaran materi system gerak dengan model pembelajaran TGT secara bersinergi dapat meningkatkan pemahaman siswa terhadap konsep system gerak, sehingga dapat meningkatkan hasil belajarnya. Perbandingan hasil belajar sebelum dilakukan TGT, siklus I dan siklus II dapat dilihat pada Tabel berikut:

Tabel. Perbandingan Nilai Hasil Ulangan Harian Kondisi Awal, Siklus I Dan Siklus II

\begin{tabular}{cccccc}
\hline $\begin{array}{c}\text { Hasil } \\
\text { UH } \\
\text { pada }\end{array}$ & $\begin{array}{c}\text { Nila } \\
\text { i } \\
\text { Min }\end{array}$ & $\begin{array}{c}\text { Nila } \\
\text { Ma } \\
\text { x }\end{array}$ & $\begin{array}{c}\text { Nilai } \\
\text { rata- } \\
\text { rata }\end{array}$ & $\begin{array}{c}\text { Siswa } \\
\text { Tunta } \\
\text { s }\end{array}$ & $\%$ \\
\hline awal & 40,0 & 75,0 & 60,97 & 13 & 41,9 \\
\hline Siklus I & 47,0 & 87,0 & 66,65 & 13 & 41,9 \\
\hline $\begin{array}{c}\text { Siklus } \\
\text { II }\end{array}$ & 40,0 & 90,0 & 73,06 & 26 & 83,9 \\
\hline
\end{tabular}

Dari tabel tersebut, dapat diketahui bahwa hasil belajar kelas VIIID dari kondisi awal dan siklus I tidak ada peningkatan jumlah siswa yang mencapai KKM, tetapi secara keseluruhan ada peningkatan rata-rata nilai yang dicapai walaupun belum signifikan. Namun jika dilihat dari partisipasi siswa yang cukup tinggi, yaitu 81,76\%, ini sudah merupakan kemajuan yang menggembirakan. Hal ini sesuai dengan pendapatnya Winkel, bahwa hasil belajar merupakan perubahan pelaku belajar yang meliputi perubahan pengetahuan, pemahaman, ketrampilan serta sikap dan nilai yang semuanya menunjang pekembangan anak (Winkel, 1991: 13).

Sementara antara siklus I ke siklus II terjadi peningkatan yang signifikan pada rata-rata nilai maupun jumlah siswa yang mencapai KKM. Rata-rata nilai meningkat dari 66,75 menjadi 73,06, dan ketuntasan klasikal dari 41, 94 menjadi 83,90\%. Meskipun ketuntasan klasikal yang ideal yaitu $85,00 \%$ belum tercapai, namun peningkatan yang mencapai lebih dari $100 \%$ sungguh sangat menggembirakan.

Untuk lebih jelasnya adanya peningkatan hasil belajar siswa pada tiap siklus dapat dilihat pada grafik 1 berikut. 


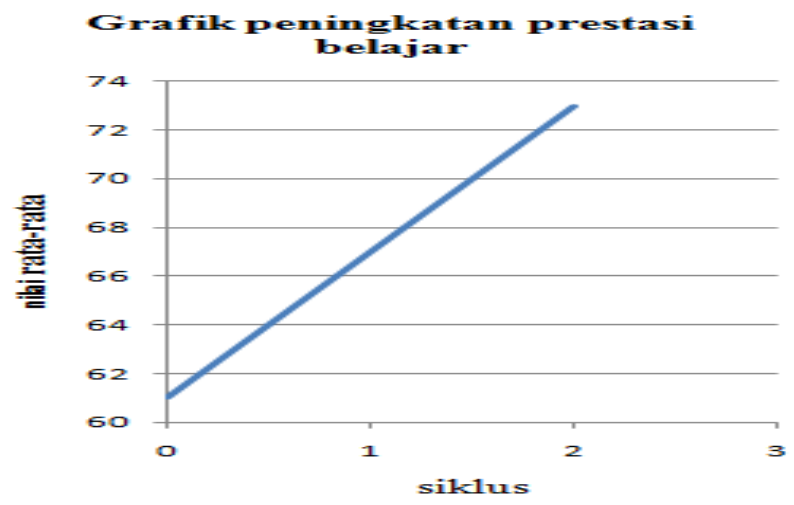

Grafik 1 Peningkatan Prestasi Belajar Siswa

Berdasarkan uraian tersebut bisa dikatakan bahwa dengan model pembelajaran TGT, dapat meningkatkan aktivitas belajar siswa. Dengan aktif dan ikut berpartisapasi dalam proses pembelajaran, maka minat siswa terhadap pelajaran dapat meningkat sehingga dapat meningkatkan hasil belajarnya.

\section{KESIMPULAN}

Dari penelitian yang telah dilakukan diperoleh hasil bahwa penerapan pembelajaran TGT (Team Game Tournament) dapat meningkatkan minat dan hasil belajar konsep sistem gerak pada manusia, pada siswa kelas VIIID SMP Negeri 1 Bandungan tahun pelajaran 2013/2014. Persentase peningkatan minat sebesar $85,5 \%$ dan peningkatan hasil belajar sebesar $19,7 \%$.

Berdasarkan hasil penelitian ini direkomendasikan untuk melaksanakan penelitian lajutan menggunakan model pembelajaran TGT dengan memperhatikan faktor-faktor yang dapat mempengaruhi efektifitas dan aktivitas pembelajaran misalnya materi, pengetahuan prasarat, dan kondisi siswa. 


\section{DAFTAR PUSTAKA}

AD. Roijakkers. 2010. Mengajar Dengan Sukses. Jakarta: Grassindo.

Depdiknas. 2004. Materi Bimbingan Teknis Guru IPA Biologi .

Hazni Fazati, 2008. Peningkatan Penguasaan Kompetensi Dasar Mendiskripsikan Konsep Bunyi

Dengan Pembelajaran Kooperatif Tipe Jigsaw. Skripsi: tidak dipublikasikan.

Mikrajudin, Saktiyono, Lutfi. 2007. IPA Terpadu SMP dan MTs 2 A. Jakarta: Erlangga.

Mukhtar, Dr. M.Pd., Samsu. Drs, Rusmini. Dra. 2002. Pendidikan Anak Bangsa Pendidikan Untuk Semua. Jakarta: Nimas Multima.

Puji Rahayu, S.Pd., 2011. Peningkatan Pemahaman Menghitung Keliling dan Luas Segi Empat Melalui Pembelajaran Kooperatif TGT Pada Siswa Kelas VII. Laporan PTK: Tidak Dipublikasikan.

Saiful Karim, Ida Kaniawati, Yuli N. Fauziah. 2008. Belajar IPA Membuka Cakrawala Alam Sekitar Untuk SMP Kelas VIII. Jakarta: Depdiknas.

Slameto, 2010. Belajar Dan Faktor-faktor Yang Mempengaruhinya. Jakarta: Rineka Karya Winkel, W S. 1991. Psikologi Pengajaran. Jakarta: Grassindo 